Creative Commons User License: CC BY-NC-ND

Abstracted by: EBSCOhost, Electronic Journals Service (EJS),

Google Scholar, Journal Seek, Scientific Commons,

Food and Agricultural Organization (FAO), CABI and Scopus

http://eoi.citefactor.org/10.11226/v25i2
Journal of Agricultural Extension

Vol. 25 (2) April, 2021

ISSN(e): 24086851; ISSN(Print); 1119944X

http://journal.aesonnigeria.org

http://www.ajol.info/index.php/jae

Email: editorinchief@aesonnigeria.org

\title{
Adoption Determinants of Adapted Climate Smart Agriculture Technologies Among Smallholder Farmers in Machakos, Makueni, and Kitui Counties of Kenya
}

https://dx.doi.org/10.4314/jae.v25i2.7

\section{Muriithi Lydia N.}

Department of Agricultural Resource Management, University of Embu, Embu, Kenya

Email: muriithilydia03@gmail.com, Phone:+254706194846

\section{Onyari Charles $\mathbf{N}$.}

Department of Land and Water Management, University of Embu, Embu, Kenya

Email: onyari.charles@yahoo.com, Phone: +25421782254

\section{Mogaka Hezron R.}

Department of Agricultural Economics and Extension, University of Embu, Embu, Kenya Email: hezronmogaka@gmail.com, Phone:+254738881188

\section{Gichimu Bernard M.}

Department of Agricultural Resource Management, University of Embu, Embu, Kenya Email: wacikubm@gmail.com

\section{Gatumo Geoffrey N.}

Department of Agricultural Resource Management, University of Embu, Embu, Kenya Email: drgatumongari@gmail.com, Phone:+254733845087

\section{Kwena Kizito}

Kenya Agricultural and Livestock Research Organization (KALRO-Katumani), Machakos Email: kwenakizito@yahoo.com, Phone:+254726370808

\section{Abstract \\ The study examined the adoption determinants of adapted climate smart agriculture (CSA) technologies among smallholder farmers. A multi-stage sampling procedure was used to select a total sample of 384 households. Percentages and regression were employed in data analysis. The results revealed that $47.4 \%$ adapted to climate change using integrated farming system, intercropping, crop rotation and agroforestry. Sex (0.9\%), education level (9.2\%) significantly influenced adoption of the adaptation strategies. Moreover, information sources such as mobile phones (0.9\%), and neighbors/friends (0.2\%) negatively affected the adaptation strategies. Future policy should aim at creating more awareness through different information sources and provide local extension services.}

Keywords: Adaptation, smallholder farmers 
Creative Commons User License: CC BY-NC-ND

Abstracted by: EBSCOhost, Electronic Journals Service (EJS),

Google Scholar, Journal Seek, Scientific Commons,

Food and Agricultural Organization (FAO), CABI and Scopus

http://eoi.citefactor.org/10.11226/v25i2
Journal of Agricultural Extension

Vol. 25 (2) April, 2021

ISSN(e): 24086851; ISSN(Print); $1119944 X$

http://journal.aesonnigeria.org

http://www.ajol.info/index.php/jae

Email: editorinchief@aesonnigeria.org

\section{Introduction}

Climate change is rapidly emerging as the most challenging environmental problem affecting mny sectors in the world. Globally, continuous increase in greenhouse gases emissions has led to warming of the planet, shift in rainfall patterns, occurrence of extreme events like drought, floods and frequent outbreak of forest fires (Makate, Makate, Mango, and Siziba, 2019). In developing countries, such as Kenya, attaining agricultural sustainability which plays a critical role in food systems is a major challenge. This calls for adoption of CSA technologies that mitigate production losses and improve household welfare.

CSA incorporates a wide range of agricultural practices. Some of these practices entail crop diversification, use of drought resistant crop varieties, weather-based agro-advisories, crop rotation, intercropping, conservation agriculture (CA) and switching from crop farming to livestock keeping. Successful adoption of these strategies depends on the dissemination channels used to relay agricultural knowledge and ability of farmers to translate perceptions of climate variability into agricultural decisions (Lalani, Dorward, Holloway, and Wauters, 2016).

Technology advancement has given rise to new communication networks that are either standalone or mediated (Osei, Folitse, Dzandu, and Obeng-Koranteng, 2017). Some of the frequently used communication channels include mass media, group media, interpersonal media and climate-field-schools (CFS). In most of the rural areas, choice on the communication channel is highly dependent on socio-economic characteristics of respondents, quality of the communication infrastructure, media richness, message characteristics and availability of a feedback mechanism (Belay, Recha, Woldeamanuel, and Morton, 2017). Intensification of climate information collection, sharing and dissemination through the available sources is significant in ensuring timely delivery of necessary information to intended targets.

Various research efforts in Kenya have focused on improving rural livelihoods by increasing economic growth through the use of quality seeds, fertilizers and accessibility to agricultural information. However, there has been little focus on influence of socio-economic characteristics and appropriate dissemination channels that effectively promote adoption of CSA technologies at the household level. The study examined the factors influencing adoption of adapted climate change technologies among smallholder farmers.

\section{Methodology}

The study was conducted in three counties (Table 1). Machakos County lies between latitude $0^{\circ} 45^{\prime}$ and $1^{\circ} 31^{\prime}$ south and longitude $36^{\circ} 45^{\prime}$ and $37^{\circ}$ 45' east at an elevation of 1800 to $2100 \mathrm{~m}$ above sea level while Makueni County lies 
Creative Commons User License: CC BY-NC-ND

Abstracted by: EBSCOhost, Electronic Journals Service (EJS),

Google Scholar, Journal Seek, Scientific Commons,

Food and Agricultural Organization (FAO), CABI and Scopus

http://eoi.citefactor.org/10.11226/v25i2
Journal of Agricultural Extension

Vol. 25 (2) April, 2021

ISSN(e): 24086851; ISSN(Print); 1119944X

http://journal.aesonnigeria.org

http://www.ajol.info/index.php/jae

Email: editorinchief@aesonnigeria.org

between latitude $1^{\circ} 35^{\prime}$ and $3^{\circ} 00^{\prime}$ south and longitude $37^{\circ} 10^{\prime}$ and $38^{\circ} 30^{\prime}$ east at an elevation of 1460 to $1710 \mathrm{~m}$ above sea level. Kitui County is found between latitude $0^{\circ} 10^{\prime}$ and $3^{\circ} 0^{\prime}$ south and longitudes $37^{\circ} 50^{\prime}$ and $39^{\circ} 0^{\prime}$ east at an elevation of 400 to $1800 \mathrm{~m}$ above the sea level. Machakos County is the smallest with a total area of $6,208.2 \mathrm{~km}^{2}$ followed by Makueni with $8,008.7 \mathrm{~km}^{2}$ while Kitui is the largest County with a total area of $30,496.4 \mathrm{~km}^{2}$. The mean temperature ranges are $18-29^{\circ} \mathrm{C}, 20.2-35.8^{\circ} \mathrm{C}$ and $14-34{ }^{\circ} \mathrm{C}$, for Machakos, Makueni and Kitui, respectively. All the three counties experience a bimodal rainfall pattern.

In selecting respondents, multi-stage sampling procedure was employed. The first step involved random selection of two sub-counties in each of the three target counties (Table 1). Secondly, random drawing of two wards from each of the sub-counties was done. The third stage involved random selection of 384 households in a proportionate to size manner from a total population of 30,885 small scale farmers in the randomly selected wards. Similarly, the Kenya Agricultural and Livestock Research Organisation (KALRO) in collaboration with the Kenya Meteorological Department (KMD) had over the last three years been disseminating climate change adaptation information using different sources, including radio, short message service (SMS), television and public meetings (Muema, Mburu, Coulibaly, and Mutune, 2018).

Table 1: Distribution of respondents in the three Counties

\begin{tabular}{|c|c|c|c|c|c|}
\hline County & $\begin{array}{l}\text { Sub- } \\
\text { County }\end{array}$ & $\begin{array}{l}\text { No. of } \\
\mathrm{HH}^{*}\end{array}$ & Ward & $\begin{array}{l}\text { No. of } \\
\mathrm{HH}^{\star \star}\end{array}$ & $\begin{array}{l}\text { Sampled } \\
\text { respondents }\end{array}$ \\
\hline \multirow[t]{2}{*}{ Machakos } & Kathiani & 28,730 & Mitaboni & 7,182 & 89 \\
\hline & Kangundo & 26,142 & $\begin{array}{l}\text { Kangundo } \\
\text { North }\end{array}$ & 6,536 & 81 \\
\hline \multirow[t]{2}{*}{ Makueni } & $\begin{array}{l}\text { Kibwezi } \\
\text { West }\end{array}$ & 21,756 & Makindu & 3,626 & 45 \\
\hline & Makueni & 34,479 & Wote & 4,926 & 61 \\
\hline \multirow[t]{2}{*}{ Kitui } & Kitui South & 23,044 & Mutomo & 3,841 & 49 \\
\hline & $\begin{array}{l}\text { Mwingi } \\
\text { West }\end{array}$ & 19,096 & Nguutani & 4,774 & 59 \\
\hline Total & & 153,247 & & 30,885 & 384 \\
\hline
\end{tabular}

*Based on KNBS (2019); **Based on Ward Administrators' List

A sample size of 384 smallholder farmers was determined using the Cochran equation. Primary data was collected using semi-structured questionnaire designed in an Open Data Kit (ODK) application. The questionnaire was pretested and necessary modifications were made before being administered to solicit information on various socioeconomic and information sources that promoted adoption of specific CSA technologies. Descriptive statistics were used 
Creative Commons User License: CC BY-NC-ND

Abstracted by: EBSCOhost, Electronic Journals Service (EJS),

Google Scholar, Journal Seek, Scientific Commons,

Food and Agricultural Organization (FAO), CABI and Scopus

http://eoi.citefactor.org/10.11226/v25i2
Journal of Agricultural Extension

ISSN(e): 24086851; ISSN(Print); 1119944X

http://journal.aesonnigeria.org

http://www.ajol.info/index.php/jae

Email: editorinchief@aesonnigeria.org

in analysis and presentation of qualitative categorical data using Statistical Package for Social Sciences (SPSS) version 23. Multinomial logistic (MNL) regression model was then applied to analyze the influence of socio-economic and information sources on adoption of CSA technologies as follows;

$$
\left.P(y=j / x)=\frac{\exp \left(x B_{j}\right)}{\left[1+\sum_{h=1}^{j} \exp \left(x \beta_{h}\right), j=1 \ldots \ldots . J\right.}\right]
$$

Where $P=$ is probability, $\gamma=$ random variable taking values $\{1,2 \ldots J\}, j=$ is a positive integer, and $x=$ is a set of conditioning variables. In the study, $y$ symbolizes the adaptation alternatives (strategies) and $x$ contains some socioeconomic factors and different climate information sources.

For equation (1) parameter estimates to be unbiased and consistent, assumption of independence of irrelevant alternatives (IIA) should hold. In this case, IIA premise failed to reject the null hypothesis, indicating MNL is an appropriate model. Additionally, Variance Inflation Factor (VIF) was used to check all the explanatory variables, and was found to be less than $10(1.16-2.21)$.

\section{Results and Discussion}

\section{Socio-economic Characteristics of the Households}

Table 2 shows the socio-economic characteristics of the sampled respondents. Majority of the household heads had attained primary education (52.6\%). Most $(64.3 \%)$ of the sampled households had three to six members per household. Majority $(67.28 \%)$ owned between one to four hectares of land. In addition, majority $(64.32 \%)$ had a farming experience of more than 15 years.

Table 2: Socio-economic characteristics of the respondents

\begin{tabular}{lll}
\hline Characteristics & Category & Percentage (\%) \\
\hline Household Size & Up to 2 & 21.9 \\
& $3-6$ & 64.3 \\
Highest level of education & $7-10$ & 12.5 \\
& Above 11 & 1.3 \\
& No formal education & 8.6 \\
& Primary & 52.6 \\
Farm size in hectares & Secondary & 29.7 \\
& College & 7.6 \\
& University & 1.6 \\
& Less than 1 & 3.38 \\
Farming experience in years & $1-4$ & 67.18 \\
& $5-9$ & 21.36 \\
& $10-14$ & 4.17 \\
& More than 15 & 3.9 \\
& Less than 5 & 11.20 \\
& $5-10$ & 14.84 \\
\hline
\end{tabular}


Creative Commons User License: CC BY-NC-ND

Abstracted by: EBSCOhost, Electronic Journals Service (EJS),

Google Scholar, Journal Seek, Scientific Commons,

Food and Agricultural Organization (FAO), CABI and Scopus

http://eoi.citefactor.org/10.11226/v25i2
Journal of Agricultural Extension

Vol. 25 (2) April, 2021

ISSN(e): 24086851; ISSN(Print); 1119944X

http://journal.aesonnigeria.org

http://www.ajol.info/index.php/jae

Email: editorinchief@aesonnigeria.org

\section{Main Climate Smart Agriculture Technologies Adopted by Smallholder Farmers}

Table 3 shows that $93.2 \%$ of the sampled farmers knew the practices available for adoption and $47.4 \%$ had adopted the use of some of these technologies in their farms. This could be attributed to lack of technology trust and technical capacity among the farmers' social status, type of technology, and high cost incurred during uptake (Nyasimi, Kimeli, Sayula, Radeny, Kinyangi, and Mungai, 2017).

Table 3: Awareness and adoption of the climate smart agriculture technologies

\begin{tabular}{ll}
\hline Variable & Percentage Yes (\%) \\
\hline Awareness & 93.2 \\
Adoption of the CSA technologies & 47.4 \\
\hline
\end{tabular}

Responses of main adaptation strategies used in the region were summarized into seven major types (Table 4), as: integrated farming system (23.36\%); intercropping (16.88\%); crop rotation (15.09\%); agroforestry (12.82\%); conservation agriculture (11.99\%); crop diversification (10.06\%), and water harvesting $(9.79 \%)$. This shows that farmers in these regions have adopted major coping strategies (Table 4). These results coincide with the findings of Ryan \& Elsner (2016), who noted agroforestry, water harvesting, conservation tillage, and adjustments in farming operations as the major strategies adopted by farmers in Africa.

Table 4: Main climate smart agriculture technologies adopted in the three Counties

\begin{tabular}{ll}
\hline Climate smart agriculture technology & Percentage (\%) \\
\hline Integrated farming system & 23.36 \\
Intercropping & 16.88 \\
Crop rotation & 15.09 \\
Conservation agriculture & 11.99 \\
Crop diversification & 10.06 \\
Water harvesting & 9.79 \\
Agroforestry & 12.82 \\
\hline
\end{tabular}

\section{Sources of Climate Change Adaptation Information}

The study established that farmers interviewed received the climate change adaptation information through the radio (37.4\%), followed by neighbors and friends (24.4), extension agents (14.1\%), mobile phones (9.1\%), television 
Creative Commons User License: CC BY-NC-ND

Abstracted by: EBSCOhost, Electronic Journals Service (EJS),

Google Scholar, Journal Seek, Scientific Commons,

Food and Agricultural Organization (FAO), CABI and Scopus

http://eoi.citefactor.org/10.11226/v25i2
Journal of Agricultural Extension

Vol. 25 (2) April, 2021

ISSN(e): 24086851; ISSN(Print); $1119944 X$

http://journal.aesonnigeria.org

http://www.ajol.info/index.php/jae

Email: editorinchief@aesonnigeria.org

$(8.9 \%)$ and from local administrators (6.1\%) (Table 5). The findings corroborate with that of Aldosari, Al Shunaifi, Ullah, Muddassir, and Noor, (2019), who rated radio as the most reliable source of information. This shows that relaying relevant information on appropriate adaptation technologies through readily available sources could enhance uptake of agricultural technologies in these areas.

Table 5: Sources of climate change adaptation information

\begin{tabular}{ll}
\hline Source & Percentage (\%) \\
\hline Radio & 37.4 \\
Television & 8.9 \\
Mobile phone & 9.1 \\
Agricultural extension agents & 14.1 \\
Neighbors and friends & 24.4 \\
Local administrators & 6.1 \\
\hline
\end{tabular}

\section{Determinants of Smallholder Farmers' Adoption of Adaptation} Technologies

Table 6 shows that sex of the household head statistically and positively influenced adoption of crop rotation and agroforestry by a factor of 1.431 and 1.207 , respectively. This is particularly true in a traditional African set-up, where men make key decisions in the households. This finding agrees with that of Belay et al. (2017), that male-headed households had a better opportunity to practice adaptation, access climate information and agricultural technologies more easily than female-headed households.

Increase in the age of the household head was found to significantly reduce ability of smallholders to adopt agroforestry while it increased chances of adopting crop diversification (Table 6). This implies that as the age of the household head increased by one year, chances of using agroforestry reduced by $6.5 \%$. Usually, older farmers are more experienced and could have accumulated more knowledge and capital through the years. Totin, Segnon, Schut, Affognon, Zougmoré, Rosenstock, and Thornton, (2018) noted that despite farmers failing to consult external sources, the likelihood of adopting new farming methods was still high. On the other hand, an increase in household head age by one year increased the possibility of farmers adopting crop diversification by $22.6 \%$. The finding agrees to Saguye (2017), who noted that low adoption rates among young farmers mainly resulted from longer planning horizons and resistance to change.

The computed marginal effects for household head level of education indicated a positive and significant impact of farmers' decision to adopt crop rotation, agroforestry and crop diversification by $0.3 \%$. $9.2 \%$ and $6.5 \%$, respectively 
Creative Commons User License: CC BY-NC-ND

Abstracted by: EBSCOhost, Electronic Journals Service (EJS),

Google Scholar, Journal Seek, Scientific Commons,

Food and Agricultural Organization (FAO), CABI and Scopus

http://eoi.citefactor.org/10.11226/v25i2
Journal of Agricultural Extension

Vol. 25 (2) April, 2021

ISSN(e): 24086851; ISSN(Print); 1119944X

http://journal.aesonnigeria.org

http://www.ajol.info/index.php/jae

Email: editorinchief@aesonnigeria.org

(Table 6). Generally, education is believed to improve an individual's reasoning capability as well as increasing awareness of viable technologies to be adopted. Therefore, this result implies that the likelihood of households with better formal education adopting appropriate climate smart technologies is higher than noneducated households. Our finding is in line with earlier empirical evidence showing the positive impacts of education on farmers' decision to adopt agricultural technologies (Tokede, Banjo, Ahmad, Fatoki, and Akanni, 2020).

Household size had a significant and positive influence on adoption of crop diversification and water harvesting practices (Table 6). The findings show that a unit increase in the family members increased the possibility of adopting the aforementioned technologies by a factor of 1.416 and 0.898 , respectively. According to Gebremariam \& Tesfaye (2018), the likely reasons why larger family sizes with many productive household members managed to reduce climate change impacts was due to availability of enough labor force.

On the other hand, farm size was found to have a significant positive association with intercropping and crop rotation (Table 6). This infers that farmers with adequate land sizes are more likely to take up intercropping and crop rotation than those with small land sizes. This was attributed to availability of adequate land as the necessary resource to facilitate the adoption of these two agricultural technologies. The outcome corroborates the study by Teshome \& Baye (2018), who observed a high probability of households with large farm sizes adopting new land management technologies as compared to those with small farm sizes.

Use of television as a source of information positively influenced adoption of conservation agriculture and agroforestry by a factor of 0.896 and 2.705, respectively (Table 6 ). This indicated that farmers who own television sets are able to access more agricultural programmes on conservation agriculture and agroforestry than those without. The finding corresponds to Muema et al. (2018), who observed that broadcasting agricultural programmes through television stations could strongly impact farmers. The results further showed that farmers' accessibility to radio had a significant negative influence on the adoption of crop diversification by $8.2 \%$. This suggested that despite many smallholder farmers owning a radio, the farmers were not fully exposed to crop diversification programmes. The finding may be explained by the earlier finding by Mtega (2018), who noted that although most farmers in Ondo state Nigeria owned a radio, $90 \%$ failed to listen to agricultural programmes.

Owning a mobile phone negatively influenced adoption of agroforestry and water harvesting at $0.9 \%$ and $0.8 \%$, respectively (Table 6 ). The low uptake among the farmers in the study area could have resulted from few farmers using it to access agricultural information. The finding is related to a study by Folitse, Manteaw, 
Creative Commons User License: CC BY-NC-ND

Abstracted by: EBSCOhost, Electronic Journals Service (EJS),

Google Scholar, Journal Seek, Scientific Commons,

Food and Agricultural Organization (FAO), CABI and Scopus

http://eoi.citefactor.org/10.11226/v25i2
Journal of Agricultural Extension

ISSN(e): 24086851; ISSN(Print); 1119944X

http://journal.aesonnigeria.org

http://www.ajol.info/index.php/jae

Email: editorinchief@aesonnigeria.org

Dzandu, Obeng-Koranteng, and Bekoe, (2019), which showed that despite ownership of mobile phones, few farmers subscribed to agricultural related short message service (SMS) and apps, thus negatively impacting rural productivity. Additionally, the results showed that access to agricultural extension services positively influenced use of intercropping and crop diversification by a factor of 0.806 and 1.433, respectively (Table 6). This result is consistent with that of Urassa \& Mvena (2016), who claimed that frequent interactions between farmers and extension agents contributes to increased awareness of agricultural technologies, thus motivating farmers to try out the technologies on-farm.

The study established that access to local administrators significantly and positively influenced adoption of crop rotation, agroforestry and crop diversification by a factor of 2.328, 1.969 and 2.071, respectively (Table 6). The positive $\beta$ coefficient could result from easier access of smallholder farmers to their local administrators like the chief and village elders in the sampled regions. According to Ketema and Kebede (2017), frequent farmer to local administrator's interactions permitted easy access of appropriate agricultural knowledge. On the other hand, information obtained from neighbours and friends was found to have a significant adverse effect on adoption of crop rotation, agro-forestry and crop diversification by a factor of $0.257,1.390$ and 1.511, respectively (Table 6). The negative influence could be due to other farmers' not having adequate and reliable knowledge on proper use of these technologies in their farms. A study by Mekonnen, Gerber, and Matz, (2018), also identified that having a larger network of neighbors slowed adoption of improved cereal varieties among Ethiopian farmers. 
Creative Commons User License: CC BY-NC-ND

Abstracted by: EBSCOhost, Electronic Journals Service (EJS),

Google Scholar, Journal Seek, Scientific Commons,

Food and Agricultural Organization (FAO), CABI and Scopus

http://eoi.citefactor.org/10.11226/v25i2
Journal of Agricultural Extension

ISSN(e): 24086851; ISSN(Print); 1119944X

http://journal.aesonnigeria.org

http://www.ajol.info/index.php/jae

Email: editorinchief@aesonnigeria.org

Table 6: Factors influencing farmers adoption of climate change adaptation technologies

\begin{tabular}{|c|c|c|c|c|c|c|}
\hline Variable & $\begin{array}{c}\text { Intercropping } \\
\beta \text { Coef } \\
\text { P-value }\end{array}$ & $\begin{array}{c}\text { Crop } \\
\text { rotation } \\
\beta \text { Coef } \\
\text { P-value }\end{array}$ & $\begin{array}{c}\text { Conservation } \\
\text { agriculture } \\
\beta \text { Coef } \\
\text { P-value }\end{array}$ & $\begin{array}{c}\text { Agroforestry } \\
\beta C \text { Coef } \\
\text { P-value }\end{array}$ & $\begin{array}{c}\text { Crop } \\
\text { diversification } \\
\beta \text { Coef } \\
\text { P-value }\end{array}$ & $\begin{array}{l}\text { Water } \\
\text { harvesting } \\
\beta \text { Coef } \\
\text { P-value }\end{array}$ \\
\hline \multicolumn{7}{|c|}{ The effect of socio-economic characteristics on farmers' choice of adaptation technologies } \\
\hline Sex & $\begin{array}{c}0.367 \\
(0.320)\end{array}$ & $\begin{array}{c}1.431 \\
(0.000)^{* * *}\end{array}$ & $\begin{array}{c}0.223 \\
(0.555)\end{array}$ & $\begin{array}{c}1.207 \\
(0.009)^{\star \star \star}\end{array}$ & $\begin{array}{c}0.353 \\
(0.316)\end{array}$ & $\begin{array}{c}0.241 \\
(0.537)\end{array}$ \\
\hline Age & $\begin{array}{l}-0.676 \\
(0.222)\end{array}$ & $\begin{array}{l}-0.121 \\
(0.461)\end{array}$ & $\begin{array}{l}-0.430 \\
(0.445)\end{array}$ & $\begin{array}{c}-1.539 \\
(0.065)^{*}\end{array}$ & $\begin{array}{c}0.226 \\
(0.068)^{*}\end{array}$ & $\begin{array}{l}-0.062 \\
(0.912)\end{array}$ \\
\hline $\begin{array}{l}\text { Education } \\
\text { level }\end{array}$ & $\begin{array}{c}0.054 \\
(0.503)\end{array}$ & $\begin{array}{c}1.223 \\
(0.003)^{\star \star}\end{array}$ & $\begin{array}{r}0.0 \\
(0.9\end{array}$ & $\begin{array}{c}0.018 \\
(0.092)^{*}\end{array}$ & $\begin{array}{c}1.046 \\
(0.065)^{*}\end{array}$ & $\begin{array}{l}-0.010 \\
(0.922)\end{array}$ \\
\hline Household & -0.010 & 0.371 & 0.540 & -0.204 & 1.416 & 0.898 \\
\hline size & $(0.982)$ & $(0.424)$ & $(0.253)$ & $(0.731)$ & $(0.020)^{\star *}$ & $(0.092)^{\star}$ \\
\hline Farm size & $\begin{array}{c}0.290 \\
(0.005)^{\star * *}\end{array}$ & $\begin{array}{c}0.284 \\
(0.040)^{\star *}\end{array}$ & $\begin{array}{c}0.368 \\
(0.245)\end{array}$ & $\begin{array}{c}0.221 \\
(0.508)\end{array}$ & $\begin{array}{l}-1.111 \\
(0.629)\end{array}$ & $\begin{array}{c}0.089 \\
(0.194)\end{array}$ \\
\hline \multicolumn{7}{|c|}{ The effect of information sources on the farmers' choice of adaptation technologies } \\
\hline TV & $\begin{array}{c}0.671 \\
(0.173)\end{array}$ & $\begin{array}{l}-0.024 \\
(0.965)\end{array}$ & $\begin{array}{c}0.896 \\
(0.064)^{*}\end{array}$ & $\begin{array}{c}2.705 \\
(0.000)^{\star * *}\end{array}$ & $\begin{array}{c}0.605 \\
(0.220)\end{array}$ & $\begin{array}{c}0.179 \\
(0.762)\end{array}$ \\
\hline Radio & $\begin{array}{l}-0.304 \\
(0.651)\end{array}$ & $\begin{array}{l}-0.148 \\
(0.827)\end{array}$ & $\begin{array}{l}-0.275 \\
(0.681)\end{array}$ & $\begin{array}{c}0.149 \\
(0.874)\end{array}$ & $\begin{array}{c}-1.012 \\
(0.082)^{\star *}\end{array}$ & $\begin{array}{l}1.297 \\
(0.236)\end{array}$ \\
\hline $\begin{array}{l}\text { Mobile } \\
\text { phone }\end{array}$ & $\begin{array}{c}0.349 \\
(0.392)\end{array}$ & $\begin{array}{l}-0.531 \\
(0.252)\end{array}$ & $\begin{array}{l}-0.628 \\
(0.206)\end{array}$ & $\begin{array}{c}-2.128 \\
(0.009)^{\star \star *}\end{array}$ & $\begin{array}{l}-0.212 \\
(0.607)\end{array}$ & $\begin{array}{c}-2.096 \\
(0.008)^{\star * *}\end{array}$ \\
\hline $\begin{array}{l}\text { Agricultural } \\
\text { Extension } \\
\text { Agents }\end{array}$ & $\begin{array}{c}0.806 \\
(0.042)^{\star *}\end{array}$ & $\begin{array}{l}-0.046 \\
(0.913)\end{array}$ & $\begin{array}{l}-0.020 \\
(0.965)\end{array}$ & $\begin{array}{l}-0.631 \\
(0.294)\end{array}$ & $\begin{array}{c}1.433 \\
(0.000)^{\star * \star}\end{array}$ & $\begin{array}{c}0.189 \\
(0.672)\end{array}$ \\
\hline $\begin{array}{l}\text { Local } \\
\text { administrator }\end{array}$ & $\begin{array}{c}0.396 \\
(0.552)\end{array}$ & $\begin{array}{c}2.328 \\
(0.000)^{\star \star \star}\end{array}$ & $\begin{array}{l}-0.728 \\
(0.513)\end{array}$ & $\begin{array}{c}1.969 \\
(0.011)^{* *}\end{array}$ & $\begin{array}{c}2.071 \\
(0.000)^{* * *}\end{array}$ & $\begin{array}{c}0.845 \\
(0.232)\end{array}$ \\
\hline $\begin{array}{l}\text { Neighbors } \\
\text { and friends }\end{array}$ & $\begin{array}{l}-0.394 \\
(0.324)\end{array}$ & $\begin{array}{c}-0.769 \\
(0.053)^{\star *}\end{array}$ & $\begin{array}{l}-0.257 \\
(0.519)\end{array}$ & $\begin{array}{c}-1.390 \\
(0.002)^{\star * *}\end{array}$ & $\begin{array}{c}-1.511 \\
(0.000)^{\star * *}\end{array}$ & $\begin{array}{c}0.027 \\
(0.949)\end{array}$ \\
\hline
\end{tabular}

Reference category $=$ Integrated farming system, Number of observations $=384$, Asterisks ${ }^{* * *},{ }^{* *}$ and ${ }^{*}$ signify significance at $1 \%, 5 \%$ and $10 \%$ level. LR chi ${ }^{2}$ $=203.584$, Prob $>X^{2}=0.000$, Pseudo $R^{2}=0.556$, Log-likelihood $=-575.165$ 
Creative Commons User License: CC BY-NC-ND

Abstracted by: EBSCOhost, Electronic Journals Service (EJS),

Google Scholar, Journal Seek, Scientific Commons,

Food and Agricultural Organization (FAO), CABI and Scopus

http://eoi.citefactor.org/10.11226/v25i2
Journal of Agricultural Extension

Vol. 25 (2) April, 2021

ISSN(e): 24086851; ISSN(Print); 1119944X

http://journal.aesonnigeria.org

http://www.ajol.info/index.php/jae

Email: editorinchief@aesonnigeria.org

\section{Conclusion and Recommendations}

Most of the farmers in lower Eastern region of Kenya are conscious of climate change and sources for communicating climate information. Additionally, farmers' capacity to effectively adopt various adaptation practices is influenced by specific socio-economic factors and access to climate information. There is need to encourage smallholder farmers to adopt and use most of the disseminated technologies in their farms. Local administrators should frequently organize agricultural meetings so as to equip farmers with relevant knowledge that will enhance adoption of CSA technologies.

\section{Acknowledgement}

The authors appreciate International Development Research Centre (IDRC) through the project Climate Change Adaptation and ICT (CHAI) for funding this study.

\section{Reference}

Aldosari, F., Al Shunaifi, M. S., Ullah, M. A., Muddassir, M., \& Noor, M. A. (2019). Farmers' perceptions regarding the use of information and communication technology (ICT) in Khyber Pakhtunkhwa, Northern Pakistan. Journal of the Saudi Society of Agricultural Sciences, 18(2), pp211-217.

Belay, A., Recha, J. W., Woldeamanuel, T., \& Morton, J. F. (2017). Smallholder farmers' adaptation to climate change and determinants of their adaptation decisions in the Central Rift Valley of Ethiopia. Agriculture and Food Security, 6(1), pp1-13.

Folitse, B. Y., Manteaw, S. A., Dzandu, L. P., Obeng-Koranteng, G., \& Bekoe, S. (2019). The determinants of mobile-phone usage among small-scale poultry farmers in Ghana. Information Development, 35(4), pp564-574.

Gebremariam, G., \& Tesfaye, W. (2018). The heterogeneous effect of shocks on agricultural innovations adoption: Micro econometric evidence from rural Ethiopia. Food Policy, 74, pp154-161.

Ketema, M., \& Kebede, D. (2017). Adoption intensity of inorganic fertilizers in maize production: empirical evidence from smallholder farmers in eastern Ethiopia. Journal of Agricultural Science, 9(5), pp124-132.

Lalani, B., Dorward, P., Holloway, G., \& Wauters, E. (2016). Smallholder farmers' motivations for using conservation agriculture and the roles of yield, labour and soil fertility in decision making. Agricultural Systems, 146, pp80-90.

Makate, C., Makate, M., Mango, N., \& Siziba, S. (2019). Increasing resilience of smallholder farmers to climate change through multiple adoption of proven climate-smart agriculture innovations. Lessons from Southern Africa. Journal of Environmental Management, 231(August 2018), pp858-868.

Mekonnen, D. A., Gerber, N., \& Matz, J. A. (2018). Gendered social networks, agricultural innovations, and farm productivity in Ethiopia. World Development, 105, pp321-3355.

Mtega, W. P. (2018). The Usage of Radio and Television as Agricultural Knowledge Sources: The Case of Farmers in Morogoro Region of Tanzania. International Journal of Education and Development using Information and Communication Technology, 14(3), pp252-266. 
Creative Commons User License: CC BY-NC-ND

Abstracted by: EBSCOhost, Electronic Journals Service (EJS),

Google Scholar, Journal Seek, Scientific Commons,

Food and Agricultural Organization (FAO), CABI and Scopus

http://eoi.citefactor.org/10.11226/v25i2
Journal of Agricultural Extension

Vol. 25 (2) April, 2021

ISSN(e): 24086851; ISSN(Print); 1119944X

http://journal.aesonnigeria.org

http://www.ajol.info/index.php/jae

Email: editorinchief@aesonnigeria.org

Muema, E., Mburu, J., Coulibaly, J., \& Mutune, J. (2018). Determinants of access and utilisation of seasonal climate information services among smallholder farmers in Makueni County, Kenya. Heliyon, 4(11), e00889.

Nyasimi, M., Kimeli, P., Sayula, G., Radeny, M., Kinyangi, J., \& Mungai, C. (2017). Adoption and dissemination pathways for climate-smart agriculture technologies and practices for climate-resilient livelihoods in Lushoto, Northeast Tanzania. Climate, 5(3), pp63.

Osei, S. K., Folitse, B. Y., Dzandu, L. P., \& Obeng-Koranteng, G. (2017). Sources of information for urban vegetable farmers in Accra, Ghana. Information Development, 33(1), pp72-79.

Ryan, C., \& Elsner, P. (2016). The potential for sand dams to increase the adaptive capacity of East African drylands to climate change. Regional Environmental Change, 16(7), pp2087-2096.

Saguye, T. S. (2017). Determinants of adoption of sustainable land management (SLM) practices among smallholder farmers' in Jeldu District, West Shewa Zone, Oromia Region, Ethiopia. Global Journal of Science Frontier Research, 7, pp60-76.

Teshome, M., \& Baye, A. (2018). Climate variability, communities' perceptions and land management strategies in Lay Gayint Woreda, Northwest Ethiopia. Journal of Degraded and Mining Lands Management, 5(3), pp1217.

Tokede, A. M., Banjo, A. A., Ahmad, A. O., Fatoki, O. A., \& Akanni, O. F. (2020). Farmers' knowledge and attitude towards the adoption of agroforestry practices in Akinyele Local Government Area, Ibadan, Nigeria. Journal of Applied Sciences and Environmental Management, 24(10), pp1775-1780.

Totin, E., Segnon, A. C., Schut, M., Affognon, H., Zougmoré, R. B., Rosenstock, T., \& Thornton, P. K. (2018). Institutional perspectives of climate-smart agriculture: A systematic literature review. Sustainability, 10(6), pp1990.

Urassa, N. S., \& Mvena, Z. S. K. (2016). Determinants of the use of cell phones in access to beef cattle market information for smallholders in Mpwapwa District, Tanzania. Journal of the Open University of Tanzania, 22(1), pp116-131. 